\title{
Aa@
}

Autobiografia. Literatura. Kultura. Media

nr 1 (16) 2021 | s. 9-19

ISSN (print) 2353-8694

ISSN (online) 2719-4361

DOI: 10.18276/au.2021.1.16-01

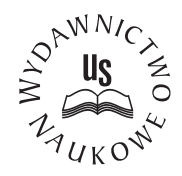

OPEN $\bigcirc$ ACCESS

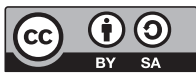

WSTĘP

JERZY MADEJSKI*

Uniwersytet Szczeciński

\section{Zegar tyka}

\section{Streszczenie}

Autor krótko uzasadnia koncepcję chronopoetyki. Odwołuje się do aforystyki Leca, do liryki i do prozy autobiograficznej Aleksandra Wata. Chronopoetyka eksponuje zegar jako przedmiot przedstawiony w literaturze oraz jako nośnik problematyki filozoficznej, nowoczesnego przeżywania czasu. Autor w swoich rozpoznaniach koncentruje się zwłaszcza na motywie bicia zegara (tik-tak).

Słowa kluczowe

autobiografia, chronopoetyka, Stanisław Jerzy Lec, Aleksander Wat, zegar, zegarmistrz, tik-tak

W świetnym artykule, opublikowanym dawno temu w „Pamiętniku Literackim”, Karl Dedecius pisał o twórczości autora Myśli nieuczesanych:

Lec był niewątpliwie poetą. Ale właśnie w skondensowanych do ostatecznych granic „myślach nieuczesanych” udawała mu się rzecz w sztuce poetyckiej najrzadsza: sublimacja gorzkiego losu ludzkości i własnej sceptycznej zadumy - w słowach, z których

\footnotetext{
* Kontakt z autorem: jerzy.madejski@usz.edu.pl; ORCID: 0000-0003-2911-2770.
} 
wyeliminowano wszystko, co mogłoby być zbyteczne. Była to najbardziej oryginalna, silna, wyjątkowa strona jego talentu, talentu, jaki zdarza się bodajże raz na sto lat ${ }^{1}$.

W innych miejscach szkicu Dedecius przekonująco uzasadnia swoją tezę o wyjątkowej randze pisarstwa Leca. A w jednym z akapitów dookreśla jego poetykę zwięzłości. Cytuje dwa aforyzmy - „Czas bije. Wszystkich” oraz „Sumienie miał czyste. Nie używane” ${ }^{2}$. Rzeczywiście zbudowane są one na podstawie tej samej zasady, tezy i swoistego dopowiedzenia; obserwacji i uzupełnienia, które zmienia charakter wypowiedzi. Interesuje mnie ten pierwszy aforyzm.

Znamienna jest tu Lecowska semantyka. Metafora „czas bije” wydaje się zrazu nazbyt śmiała (bo abstrakcyjna), choć znaleźlibyśmy dla niej motywację w licznych przysłowiach i związkach frazeologicznych. A jednak można by się zastanawiać, czy w tej sentencji wszystko gra. Dedecius - jak zaznaczyłem - interesuje się w tym aforyzmie skrótowością. A więc doprowadzeniem skomplikowanych myśli i obserwacji do postaci zdania (tu dwu wypowiedzeń). Warto jednak pytać o problematykę zawartą w tej konstrukcji. Pamiętamy, że Lec wielokrotnie w swoich sentencjach pisał o czasie. Oto kilka z nich: „Czas jest nieruchomy. Tylko się w nim posuwamy w niewłaściwym kierunku” (s. 55)3 ; „Życie zabiera ludziom zbyt wiele czasu” (s. 56); „Czas pozostanie ludożercą” (s. 123); „Już mało czasu. Wciąż grozi nam wieczność” (s. 245); „Wieczność? Jednostka czasu” (s. 264); „Czas - najważniejszy surowiec” (s. 298); „Czas zabija datownikiem” (s. 443); „»Czasem« - w tym słowie tkwi wieczność” (s. 546).

Łatwo zauważyć, że te aforyzmy łączą się z filozofią. Jeśli jest tu różnica pomiędzy Lecem a jego poprzednikami, dotyczy ona wprowadzenia ironii do rozumienia czasu. Tak jak w myśli o ludożercy. Lecz są w aforyzmach Leca i takie, które obrazują nowoczesną duchowość. Tu przeżywanie czasu łączy się z XX-wieczną rewolucją w pojmowaniu ruchu i wiąże wyobrażenia temporalne z zegarem. Rezultatem tej przemiany może być myśl „I czas Einsteina zależał od zegara miejskiego” (s. 39) albo „I wahadło idzie z czasem” (s. 135), a może i ta: „Na żadnym zegarze nie znajdziesz wskazówek do życia” (s. 9). Każdy z tych aforyzmów zasługiwałby na obszerną interpretację. Być może jednak najlepiej nowoczesny sposób obrazowania czasu oddaje myśl „Zegar tyka. Wszystkich” (s. 89).

Otóż - jak mi się wydaje - to ten aforyzm w swojej wersji cytuje Dedecius jako „Czas bije. Wszystkich”. Nie podejmuję tutaj skądinąd intrygującej kwestii, jak doszło do parafrazy Leca (czy w wyniku kontaminacji oryginału i przeróbki w trakcie przekładu na język niemiecki,

1 Karl Dedecius, „Lec: temat, forma, źródło z krótkim prologiem i epilogiem (pierwszego spotkania i ostatniego spaceru)”, Pamiętnik Literacki 2 (1973): 201.

2 Tamże, 207.

3 Wszystkie aforyzmy Leca cytuję z edycji: Stanisław Jerzy Lec, Myśli nieuczesane wszystkie, red. Lidia Kośka (Warszawa: Noir sur Blanc, 2017). 
czy w związku z tym, że Lec w minionych dekadach funkcjonował w przekazie ustnym, stąd łatwo o kolejne przekształcenia, czy może autor szkicu znał jakiś wariant autorski sentencji). Chodzi mi o to, że te dwie wersje, Dedeciusa i Leca, oddają różnicę w postrzeganiu czasu. Pierwsza wiąże się raczej z filozofią temporalności, druga - wyraża czas w powiązaniu z techniką. Te dwa aforyzmy, oryginał i przeróbka, ukazują różnicę pomiędzy dawną poetyką obrazowania chronosu a chronopoetyką.

Zauważyć trzeba, że Lec jest w tej sentencji kontynuatorem topicznych wyobrażeń czasu. I podkreślić należy, że jego aforyzm należy do serii tych najlepszych osiągnięć. Reprezentuje te utwory, które składają się z dwóch członów. Pierwszy to zwykła obserwacja. Człon drugi to swoisty dodatek, który zmienia status całej wypowiedzi. I przekształca ton utworu. A więc spostrzeżenie, a może melancholijna uwaga, brzmią inaczej, gdy są uzupełnione członem „wszystkich”. Nie chodzi zaś tu tylko o podkreślenie równości osób i stanów wobec przemijania, lecz o wyeksponowanie bezceremonialnego doświadczania czasu w nowoczesnym społeczeństwie. Tykanie bowiem odnosi się tu nie tylko do onomatopeicznego oddania pracy mechanizmu zegara, lecz także akcentuje osobisty stosunek do czasu. Bo przecież „tykać”, to też „mówić do kogoś na ty”.

Rzeczywiście XX-wieczni twórcy byli wyczuleni na odgłos pracy mechanizmu zegara, również na przesuwanie się wskazówek zegara oraz na ruch wahadła. Poświadczenie tej wrażliwości znajdziemy u największych naszych poetów. Sporo takich odniesień występuje w twórczości Tadeusza Różewicza, Zbigniewa Herberta, Mirona Białoszewskiego... Ale czy nie najdobitniej tykanie opisał Aleksander Wat? Chodzi mi o utwór bez tytułu autora Ciemnego świecidła. Nie mam wątpliwości, że liryk Aleksandra Wata to jedna z najważniejszych manifestacji XX-wiecznej wyobraźni temporalnej:

Druga. Do brzasku długo.

Krzyk mnie zbudził. Woła?

Grozi? Czaruje? Słów,

jeśli te słowa są,

nie pojmuję.

A i ton niepojęty dla mnie.

Czy warto było budzić faceta, skoro nic, absolutnie nic nie rozumie?

Prawda, po krzyku, po echu, po ciszy,

4 Hasło „tykać”, w: Wielki słownik języka polskiego, dostęp 7.12 2021, https://wsjp.pl/haslo/do_druku/33136/ tykac. 
wejdzie do sypialni posąg marmurowy

i stanie w kącie, tam, gdzie nieomal wiek temu

zegar

mosiężnym dyskiem

śmiertelnie ostrym

godził w miękkość

mego gardła.

Nie mogę powiedzieć,

że nie byłem ostrzeżony

w porę ${ }^{5}$.

Wiersz został ogłoszony przez żonę pisarza, co jest ważne, ponieważ druk w londyńskich „Wiadomościach” opatrzony został notą. Ola Watowa informuje, że utwór pochodzi z notatnika poety. Nie jest więc właściwie wierszem, lecz projektem. Są to, jak czytamy, „pierwsze rzuty wierszy” czy „obrazy wierszy” ${ }^{6}$. To istotne, bo komentarz musi tę potencjalność utworu uwzględniać.

Liryk to zapis bezsennych minut. Druga w nocy to nawet dla tych, którzy wstają wcześnie, wyzwanie. Ważne jednak, co budzi poetę. To sen, w którym ktoś „zaczepia” przebudzonego. Ale i słowa, i ton nie są zrozumiałe. Liryk ma - jak sądzę - szczególne wyznanie metapoetyckie. Nie mogę jednak tego tematu rozwinąć. Poprzestanę tylko na kilku uwagach dotyczących czasomierza.

Zegar jest tu zredukowany do wahadła porównanego do dysku. To ciekawe, bo w tym wspomnieniu nie ma nic z estetyki przedmiotu użytkowego. Zegar przywołany z dzieciństwa został opisany poprzez jeden element mechanizmu. Poeta uwypukla ciężar i kształt wahadła oraz zagrożenie fizyczne, jakie budzi (bo ostre?). Ale właśnie to hiperboliczne przedstawienie jest związane z wyobraźnią i odczuciami dziecka. Przesuwający się dysk to obraz z przeszłości, a jeszcze po wielu latach budzi grozę. Mosiężne wahadło odmierza sekundy (poprzez ruch i dźwięk). Tu jednak metalowy przedmiot staje się zmodyfikowanym przez senny koszmar narzędziem śmierci. Właściwie jest gilotyną. W każdym razie tę wizję poeta podsuwa, gdy wspomina o uderzeniu metalowego dysku w „miękkie gardło”.

A przecież na tym liryk się nie kończy. Ostatnie wersy zawierają istotną uwagę o ostrzeżeniu „w porę”. Czy to intensywne odczucie czasu z dzieciństwa było zapowiedzią doli poety? Być może. Pamiętać trzeba, że „gardło” służy do artykulacji głosek. A umiejętność

5 Aleksander Wat, Poezje zebrane, oprac. Anna Micińska, Jan Zieliński (Kraków: Znak, 1992), 434-435.

6 O.W., „Obrazy wierszy”, Wiadomości 14 (1968): 2. 
wypowiadania to jedna z wielu możliwych definicji poety. Jak to jednak zweryfikować? W tomie poezji opracowanym przez Annę Micińską i Jana Zielińskiego opublikowany został fragment noty autobiograficznej, która odnosi się do zegara dzieciństwa:

Odkąd siebie pamiętam: w kącie vis à vis mego łóżeczka stał zegar kątówka. Cyferblat z zagadkowymi znakami i ruch dwóch wskazówek był pierwszym objawem nieruchomości i zagadki ruchu. Różnica w szybkości obu wskazówek - pierwszą intuicją relatywizmu i raptowność przesunięcia ich demonstracją gry ciągłości i mutacji. Ważniejsze było wahadło: dysk z miedzi zakończony ostrym szpikulcem i po brzegach ostry. W samej regularności jego ruchów była dla mnie groźba. Nie wiem teraz, jakiej pracy niemowlęcego umysłu, w samej niezmienności i regularności ruchu wahadłowego od-do była założona konieczność jego transgresji. Zapewne nie myślałem, jakim sposobem, ale wiedziałem z pewnością, i czekałem na ten moment z trwogą, której siły i jedyności, a także antynomii nic już nigdy nie odtworzy, że wahadło sięgnie do mnie, jak ramię mego starszego brata, poprzez tę głupią kilkumetrową przestrzeń i ostrym dyskiem przerżnie moje gardło, którego słabość, miękkość, vulnérabilité, wątłość znałem od wewnątrz lepiej niż cokolwiek innego i gardła mnie odtąd fascynowały.

Nie będę mówił o akustycznych implikacjach. Ciągłość i jednakowość tyk-tak i rzadkość, oczekiwanie z biciem serduszka i niejednakowość wydzwaniania godzin dały mi poczucie dwóch wymiarów czasu: jednego zdeterminowanego i determinującego i drugiego kazualnego, wkraczającego w życie jak cud, jak przełom, jak pierwiastek szybki - dzień powszedni i święto, tło tłumu i akt pojedynczy, a że i ta alternacja powtarzała się dzień po dniu, przekonywało mnie, że akt jednorazowo mieści się w układzie zdeterminowanym większym, wyższego rzędu, że lubię, chcę się powtarzać, narzucając naturze rzeczy swój powrót. Naturalnie są to medytacje na temat moich pierwszych doznań (Quantum) świata, ale nie jestem całkowicie pewny, w sześćdziesiątym siódmym roku życia, czy nie posiadałem wtedy zdolności medytowania, potem utraconej szybko w tych latach zapomnienia, cenzury czy kwarantanny, o której mówi Freud?

Ten wyimek z autobiografii Wata mógłby być materiałem do rozbudowanej analizy. Dotyczyłaby ona spraw podstawowych, np. tego, jak jedno przeżycie przedstawione zostało w dwu rodzajach i w dwu gatunkach. Bo przecież poeta przeznacza coś innego do poetyckiego wyznania oraz do autobiografii (tak, jak ją pojmuje). Pozostawmy te intrygujące kwestie. Z punktu widzenia chronopoetyki istotne jest nie tylko to, że intymistyka może potwierdzać odczytanie liryku. Ważne, w jaki sposób poeta „oczyszcza” wspomnienie z dzieciństwa, jak

7 Wat, Poezje, 551. Zob. też O.W., „Obrazy”, Wiadomości 14 (1968): 2. 
redukuje elementy mechanizmu zegara kątówki (np. napisy na cyferblacie, rytm wahadła, dziecięcą trwogę) i dramatyzuje wyznanie.

A wspomnieć trzeba, że autobiograficzny opis zegara został opublikowany również w londyńskich „Wiadomościach” (1968, nr 14), ale we fragmencie. Całość znamy dzięki poszukiwaniom archiwalnym Adama Dziadka. W Projekcie krytyki somatycznej znajdziemy dalsze zdania, m.in. takie, które dają wgląd w rozumienie czasu Wata:

Urodziłem się tedy 1 maja 1900 roku, tuż przed majem. Data tego dnia i pierwszego roku nowego stulecia należała w mojej pamięci do tych faktów znamiennych, które są nie tyle symboliczne ile figuralne, w znaczeniu tego słowa Auerbachowskiego mimesis: dzieję się na przecięciu dwóch planów, realnego, historycznego, konkretnego i pozahistorycznego, transcendentnego. Na wulgarnym tego poczucia szczeblu manifestacje pierwszomajowe tłumów żartobliwie przypisywałem sobie, a że w dodatku do czasów ostatnich 1 maja był zarazem dniem pogodnym, w naszych stronach, zalanych słońcem, pierwszym w istocie dniem wiosny - było to dla mnie, pomimo depresyjnego od zawsze usposobienia, prognostykiem radosnej przyszłości ${ }^{8}$.

Dla Dziadka karta z autobiografii Wata jest podstawą do rekonstrukcji poetyki somatycznej. A chronopoetyka - z pewnego punktu widzenia - przylega do subdyscypliny, którą buduje polonista z Uniwersytetu Śląskiego. Toteż warto przytoczyć fragment mistrzowskiej interpretacji Dziadka, odnoszącej się do warsztatowych uwag zawartych w reminiscencji pisarza:

Wspomnienie z dzieciństwa po wielu latach w „próbie autobiografii” - zaskakujące, przesycone doświadczeniem somatycznym, wypełnione swoistą frazeologią cielesną. Pozornie drobny fakt, który być może był jednym z tych decydujących o całym życiu i kształcie dzieła. Doświadczenie somatyczne, które jest tu bardzo precyzyjnie dookreślone: słabość, miękkość, wątłość, dodatkowo jeszcze słowem z języka francuskiego vulnérabilité ('bezbronność, 'osłabienie', ale też 'wrażliwość'), towarzyszyło poecie od wczesnego dzieciństwa i z całą pewnością wywarło wielki wpływ na kształt jego tekstów. Później doszła do tego także choroba o podłożu somatycznym, która spotęgowała samo doświadczenie i jego wyraz w kolejnych tekstach'.

8 Adam Dziadek, Projekt krytyki somatycznej (Warszawa: IBL, 2014), 55.

9 Tamże. 
Do tego tekstu Dziadek powrócił, opracowując zagadnienia związane z poetyką Mojego wieku. I tu jeszcze rozbudował interpretację próby autobiograficznej Wata ${ }^{10}$.

Dopowiedzmy jednak, że chronopoetyka Wata jest ważna w kontekście historii literatury, zwłaszcza międzywojnia. Znane są np. fascynacje futuryzmu różnymi maszynami i mechanizmami, również trybikami zegara. Warto wspomnieć choćby wiersz Tytusa Czyżewskiego ${ }^{11}$.

Ale zegar (zegarek, budzik) to tylko jeden, choć najważniejszy przedmiot zainteresowania chronopoetyki. Ma ona bowiem także swojego bohatera. Jest nim zegarmistrz. W literaturze jest sporo intrygujących portretów rzemieślnika zajmującego się czasomierzami. Pozostańmy przy prozie autobiograficznej. W 1931 roku Joseph Roth opublikował tekst pt. Uzegarmistrza. Proza ta rozpina się pomiędzy dzieciństwem („Mój czas nie miał jeszcze godzin”) a końcem życia („korniki wydają taki sam odgłos jak zegary”). Literatura Rotha traktuje o miasteczku chłopięctwa i o zegarach niedostępnych dla dzieci, ponieważ „wisiały zazwyczaj nieosiągalnie wysoko albo spoczywały w kieszeniach dorosłych; otaczała je tajemnica, były kruche, nie wolno było ich brać do ręki, nie można było się nimi bawić, były »nie dla dzieci« - słusznie»"12.

Pisarz przypomina sobie zakład rzemieślniczy i zegarmistrza, który był młody, ale jednak robił wrażenie starca: „Tak jak gdyby na jego życie przypadał nie jeden czas, lecz wiele, skutkiem licznych zegarów, które go otaczały..."13.

Sebald, komentując miniaturę prozatorską austriackiego pisarza, zauważył, że praca zegarmistrza wynika z ufności, że korekta mechanizmu przywraca ład świata ${ }^{14}$. Pozostawiam na boku, czyli do opracowania, kwestię, jak ta filozofia zegarmistrza może być wyjaśniona w kontekście austromodernizmu, o którym pisała w świetnym studium Marjorie Perloff. W każdym razie rozpoznanie amerykańskiej badaczki dobrze objaśnia zarówno cytat z powieści Rotha Marsz Radetzky'ego („Jakaś mucha bzyknęła, zegar ścienny zaczął bić”) ${ }^{15}$, jak i wers z liryku Kolonia Paula Celana („wy, zegary, głęboko w nas”) ${ }^{16}$.

I w naszej literaturze mamy wyborne opisy zegarmistrzów. Na przykład w Zmierzchach i porankach Piotra Szewca. Także ten bohater zasługuje na szerszy opis w kontekście

10 Adam Dziadek, ,»Mój wiek« Aleksandra Wata - uwagi do przyszłej edycji”, Pamiętnik Literacki 4 (2020): 215-217.

11 Tytus Czyżewski, Poezje i próby dramatyczne, oprac. Alicja Baluch (Wrocław: Ossolineum, 1992), 114-115.

12 Joseph Roth, „U zegarmistrza”, w: Proza podróżna, tłum. Małgorzata Łukasiewicz, wstep Ewa Lipska (KrakówBudapeszt-Syrakuzy: Wydawnictwo Austeria, 2018), 159.

13 Tamże, 160.

14 W.G. Sebald, Opis nieszczęścia. Eseje o literaturze, tłum. Małgorzata Łukasiewicz (Wrocław: Wydawnictwo Ossolineum, 2018).

15 Marjorie Perloff, Ostrze ironii. Modernizm w cieniu monarchii habsburskiej, tłum. Maciej Płaza (Wrocław: Wydawnictwo Ossolineum, 2018), 111.

16 Tamże, 271. 
geopoetyki, poetyki miasta (galicyjskiego), a przede wszystkim ze względu na rekonstrukcję polifonii czasomierzy naprawianych i regulowanych przez zegarmistrza:

Chaim Brondwein słyszał zegary naraz i z osobna, z ledwo słyszalnego szumu ich mechanizmów wyławiał poszczególne głosy, które różniły się tak dalece, że pozwalały się rozpoznać, a więc istnieć samodzielnie i być może ku swojemu tylko pożytkowi. Sekundniki pędziły w szaleńczym pościgu za czymś, co wydawało się umykać tuż przed nimi, wciąż nieuchwytne, choć niemal dotykalne, niewidzialne, a prawie cielesne, o trzy milimetry, o milimetr wyprzedzające, zawsze wcześniej, mimo że meta pozostawała bardziej domysłem niż realnym faktem. Czy widział metę Chaim Brondwein, gdy zakładał na oczy szkła powiększające i przybliżał tarcze, na których odbywał się ten niemający finału pościg? ${ }^{17}$

W prozie Szewca ważna jest jeszcze inna okoliczność. Detaliczny opis bogactwa dźwięków, sygnalizujący rozmaitość wytworów człowieka oraz różnorodność kulturową mieszkańców przedwojennego miasta, trzeba skontrastować z opisem przedmiotów w opowiadaniach Tadeusza Borowskiego. W Proszę państwa do gazu mamy wyliczenie przedmiotów pozostawionych na rampie. Wśród nich jest zegarek:

Rośnie kupa rzeczy, walizek, tłumoków, plecaków, pledów, ubrań, torebek, które padając otwierają się i wysypują barwne, tęczowe banknoty, złoto, zegarki; przed drzwiami wagonów piętrzą się stosy chleba, gromadzą słoiki różnobarwnych marmolad, powideł, pęcznieją zwały szynek, kiełbasy, rozsypuje się po żwirze cukier ${ }^{18}$.

Zegarmistrz musi być ważny również w naszej wyobraźni, skoro ma swoje hasło w „encyklopedii” Gonçalo Tavaresa. Według portugalskiego pisarza zegarmistrz tylko udaje, że jest specjalistą od mechanizmu, od trybików. W istocie jest fachowcem od czasu. Naprawianie zegarów to jedynie przygotowanie do o wiele ważniejszej profesji filozofa ${ }^{19}$.

Wreszcie chronopoetyka ma swoje poetologie. Za taką uznałbym znakomity tom Franka Kermode’a, Znaczenie końca. Nie tylko dlatego, że zawiera wykład literatury problematyzowanej z punktu widzenia czasu. W książce angielskiego badacza znajdziemy szczególny hymn o tykaniu:

17 Piotr Szewc, Zmierzchy i poranki (Kraków: Wydawnictwo Literackie, 2000), 27.

18 Tadeusz Borowski, Wspomnienia, wiersze, opowiadania, posłowie, wyb. Tadeusz Drewnowski (Warszawa: PIW, 1977), 179.

19 Hasło: „Zegarmistrz, muzyk”, w: Gonçalo M. Tavares, Encyklopedia. Notatki, tłum. Wojciech Charchalis (Gdańsk: słowo/obraz terytoria, 2018), 59-60. 
Przyjrzyjmy się bardzo prostemu przykładowi, tykaniu zegara. Pytamy, co mówi - zgadzamy się, że mówi: tik-tak. Poprzez tę fikcję humanizujemy zegar, sprawiamy, że przemawia naszym językiem. I oczywiście, to my wprowadzamy fikcyjną różnicę między oboma dźwiękami; tik jest naszym słowem na oznaczenie fizycznego rozpoczęcia, tak naszym słowem na oznaczenie końca. Mówimy, że są różne. Na odmienność pozwala im to, co jest pomiędzy. Jesteśmy w stanie percypować trwanie jedynie wtedy, kiedy jest ono zorganizowane $^{20}$.

To rozumienie tykania jest wprowadzeniem do morfologii narracji, do modelowego pojmowania epiki. Ale ruch wahadła stanowi w wykładni Kermode’a również okazję, by do objaśniania literatury wprowadzić teologiczne rozróżnienia czasu na chronos (czas obiektywny) i kairos (czas subiektywny) ${ }^{21}$. Przyjęły się one w literaturze, a także w metodologii historii. Wreszcie zaś tom Kermode’a, łączący sugestywnie bicie zegara z problematyką temporalną, wpłynął na literaturę (i film). Wykorzystał ją w swojej powieści Julian Barnes, już w tytule nawiązując do klasycznej rozprawy. Nazwał swoją książę Poczucie kresu, czyli tak samo jak Kermode swoje studium (The Sense of an Ending). A to tylko jeden z wielu sposobów wykorzystania inspiracji. Bo już w początkowej partii powieści pojawia się w przekształceniu epickim motyw z książki Kermode’a:

Nie, chodzi mi o zwykły, codzienny czas, który upływa regularnie, o czym przekonują nas zegarki i zegary: tik-tak, tik-tak. Czy istnieje coś bardziej wiarygodnego niż duża wskazówka? Jednak wystarczy drobna przyjemność czy nieznaczny ból, by uświadomić nam plastyczność czasu. Niektóre emocje przyspieszają jego bieg, inne sprawiają, że zwalnia; niekiedy zdaje się znikać - aż do tego końcowego punktu, kiedy naprawdę znika, by nigdy więcej nie wrócić22.

Powieść Barnesa doczekała się u nas wnikliwej interpretacji, uwzględniającej bogate odwołania do rozprawy Kermode’a. Nie mogę przytoczyć subtelnej wykładni Romy Sendyki dotyczącej fundamentalnej różnicy pomiędzy czasem obiektywnym a subiektywnym, tak jak gospodaruje nim angielski powieściopisarz ${ }^{23}$.

\footnotetext{
${ }^{20}$ Frank Kermode, Znaczenie końca, tłum. Olga i Wojciech Kubińscy (Gdańsk: Wydawnictwo Uniwersytetu Gdańskiego, 2010), 40.

21 Tamże, 41.

22 Julian Barnes, Poczucie kresu, tłum. Jan Kabat (Warszawa: Świat Książki, 2018), 10.

23 Roma Sendyka, „Poczucie kresu, znaczenie końca”, w: Scenariusze końca. Zmierzch, kres, apokalipsa, wybór, red. i wstęp Dariusz Czaja (Wołowiec: Wydawnictwo Czarne, 2015), 27-45.
} 
Odnotować należy usiłowania konstruowania chronopoetyki i w naszym literaturoznawstwie. Czy nie najambitniejszą próbą jest tom opracowany przez badaczy z Uniwersytetu Warmińsko-Mazurskiego? W każdym razie książka zawiera nie tylko zestaw artykułów omawiających problematykę temporalną w porządku historycznym, lecz także pewną propozycję terminologiczną. Ten nowy dział dociekań literaturoznawczych miałby mieć nazwę chronozofia ${ }^{24}$.

\section{Bibliografia}

Barnes, Julian. Poczucie kresu. Tłum. Jana Kabat. Warszawa: Świat Książki, 2018.

Borowski, Tadeusz. Wspomnienia, wiersze, opowiadania, wyb. Tadeusz Drewnowski. Warszawa: PIW, 1977.

Chojnowski, Zbigniew. „Człowiek, czas, zegar, czyli zaproszenie do refleksji chronozoficznej”. W: W rytmie zegara... Wokót zagadnień chronozoficznych, red. Zbigniew Chojnowski, Beata Kurządkowska, Anna Rzymska, 9-16. Olsztyn: Wydawnictwo Uniwersytetu Warmińsko-Mazurskiego, 2015.

Czyżewski, Tytus. Poezje i próby dramatyczne, oprac. Alicja Baluch. Wrocław: Ossolineum, 1992. Dedecius, Karl. „Lec: temat, forma, źródło z krótkim prologiem i epilogiem (pierwszego spotkania i ostatniego spaceru)”. Pamiętnik Literacki 2 (1973): 199-211.

Dziadek, Adam. „»Mój wiek« Aleksandra Wata - uwagi do przyszłej edycji”. Pamiętnik Literacki 4 (2020): 203-219.

Dziadek, Adam. Projekt krytyki somatycznej. Warszawa: IBL, 2014.

Hasło „tykać”. W: Wielki słownik języka polskiego. Dostęp 7.12 2021. https://wsjp.pl/haslo/do_ druku/33136/tykac.

Hasło: „Zegarmistrz, muzyk”. W: Gonçalo M. Tavares, Encyklopedia. Notatki. Tłum. Wojciech Charchalis, 59-60. Gdańsk: słowo/obraz terytoria, 2018.

Kermode, Frank. Znaczenie końca. Tłum. Olga i Wojciech Kubińscy. Gdańsk: Wydawnictwo Uniwersytetu Gdańskiego, 2010.

Lec, Stanisław Jerzy. Myśli nieuczesane wszystkie, red. Lidia Kośka. Warszawa: Noir sur Blanc, 2017. O.W. „Obrazy wierszy”. Wiadomości 14 (1968): 2.

Perloff, Marjorie. Ostrze ironii. Modernizm w cieniu monarchii habsburskiej. Tłum. Maciej Płaza. Wrocław: Wydawnictwo Ossolineum, 2018.

24 Zbigniew Chojnowski, „Człowiek, czas, zegar, czyli zaproszenie do refleksji chronozoficznej”, w: W rytmie zegara... Wokół zagadnień chronozoficznych, red. Zbigniew Chojnowski, Beata Kurządkowska, Anna Rzymska (Olsztyn: Wydawnictwo Uniwersytetu Warmińsko-Mazurskiego, 2015), 9-16. 
Roth, Joseph. „U zegarmistrza”. W: Proza podróżna. Tłum. Małgorzata Łukasiewicz, wstęp Ewa Lipska, 159-161. Kraków-Budapeszt-Syrakuzy: Wydawnictwo Austeria, 2018.

Sebald, W.G. Opis nieszczęścia. Eseje o literaturze. Tłum. Małgorzata Łukasiewicz. Wrocław: Wydawnictwo Ossolineum, 2019.

Sendyka, Roma, „Poczucie kresu, znaczenie końca”. W: Scenariusze końca. Zmierzch, kres, apokalipsa, wyb., red. i wstęp Dariusz Czaja, 27-45. Wołowiec: Wydawnictwo Czarne, 2015.

Szewc, Piotr. Zmierzchy i poranki. Kraków: Wydawnictwo Literackie, 2000.

Wat, Aleksander. Poezje zebrane, oprac. Anna Micińska, Jan Zieliński. Kraków: Znak, 1992.

\section{The clock is ticking}

Summary

The author briefly justifies the concept of chronopoetics. He refers to Lec's aphorism, to Aleksander Wat's poetry and his autobiographical prose. Chronopoetics exposes the clock as an object presented in literature and as a carrier of philosophical issues, of a modern experience of time. The author's explorations focus especially on the motif of the clock striking (tick tock).

Keywords

autobiography, chronopoetics, Stanisław Jerzy Lec, Aleksander Wat, clock, watchmaker, tick tock

Translated by Jerzy Madejski

PROSIMY O CYTOWANIE ARTYKUŁU JAKO:

Jerzy Madejski, „Zegar tyka”, Autobiografia. Literatura. Kultura. Media 1 (2021), 16: 9-19.

DOI: 10.18276/au.2021.1.16-01 